\title{
Causality Relation between FDI Inflows and Economic Growth in
} Qatar

\author{
Mohammed Ameen Fadhil ${ }^{1}$, Liu Yao ${ }^{2} \&$ Walaa Ismeal ${ }^{1}$ \\ ${ }^{1}$ College of Business Management and Accounting, Tenaga Nasional University (UNITEN), Malaysia \\ ${ }^{2}$ Faculty of Technology, University Malaysia Pahang, Kuantan, Malaysia \\ Correspondence: Mohammed Ameen Fadhil, College of Business Management and Accounting, Tenaga Nasional \\ University (UNITEN), Malaysia. E-mail: amin723293@yahoo.com
}

\author{
Received: April 11, 2012 Accepted: May 15, 2012 Online Published: July 16, 2012 \\ doi:10.5539/ijbm.v7n14p40 URL: http://dx.doi.org/10.5539/ijbm.v7n14p40
}

\begin{abstract}
These years Qatar has emerged as an important regional destination of foreign direct investment (FDI), which demonstrates the recent success of several smaller economies in attracting FDI. This paper aims to investigate the causal relationships between inward FDI and economic growth in the particular case of Qatar featured as oil production country. Vector Autoregressive (VAR) Impulse Responses and Granger Causality Tests were adopted as major research methods. Annual data set was used covering from 1990 to 2010. The main results demonstrated the bi-directional causality and long-run relationships between FDI inflows and economic growth in Qatar. And to attract FDI inflows into Qatar, the government shall continue its efforts in constructing promising economic and investment environment; but to promote economic growth, it will recourse to other original momentum.
\end{abstract}

Keywords: economic growth, FDI inflow, VAR impulse responses, granger causality test

\section{Introduction}

The relationship between foreign direct investment (FDI) inflows and economic growth has been extensively investigated in the academic field under globalization. Theoretically, FDI is widely believed to be most crucial to economic growth enhancement (Hansen \& Rand, 2006; Karimi, et al. 2009). However, the empirical research has hardly reached consensus (Reyadh \& Khalifa, 2009). Given the complex of the relationships between FDI and economic growth across countries, this paper selects Qatar as objective sample to investigate the bi-directional relationships.

Recently, Qatar has been seen a sizeable surge in FDI inflows, primarily in the sectors of enhanced oil recovery and production and in the development of the gas industry. Only from 2003 to 2006, net FDI inflows into Qatar almost tripled from US\$ 0.64 billion to US\$ 1.69 billion. In this paper, the used annual data set covers from 1990 to 2010 , considering the obvious efforts of Qatar government in liberalizing the economy started from 1990 to facilitate FDI inflows into the country more easily and adequately. Those notable reforms include enacting intellectual property right laws, allowing foreign investors to exercise full ownership in any project except those in banking, insurance and general trading where major Qatari partnership is still required; rationalizing import duty structure and reducing tariff rates on imports to comply with World Trade Organization standards; and making corporate income tax more transparent. Such measures consistent with free market and open Qatar economy have been conducted to construct a comprehensive economic and legal system to attract foreign investment.

This paper focuses on identifying the existence of the bi-directional causality between inward FDI and national economic growth. It also aims to examine the dynamic pattern of the two movements in order to propose some feasible advices. The following paper is organized as: Section two briefly reviews the related works. Section three formulates a testable hypothesis from a pictorial perspective. Section four discusses the adopted research methods. The test results and discussions are presented in Section five. Finally section six draws some conclusion.

\section{Related Work}

The Solow-type standard neoclassical growth models indicate that FDI increases the host country's growth through the capital stock by financing capital formation (Brems and Hans, 1970). But with diminishing returns to capital, the impact of FDI on growth is identical to that of domestic investment. Thus, FDI has only a "short-run" growth effect when the country moves into a new steady stage. 
In endogenous growth models, FDI integrates the application of new technologies into the production function of the host economy (Borensztein et al., 1998). In this way, FDI-related technological spill-over offsets the effects of diminishing returns to capital and keeps the economy on a long-term growth run. Furthermore, FDI augment the host country's existing knowledge stock through knowledge transfer (Karimi, et al. 2009) from labor training, skill acquisition (Hanson and Slaughter, 2003), as well as from introducing alternative managerial and organizational practice (De MelloL., 1999). FDI is also thought to open up export markets (Ghironi and Melitz, 2004) and to promote domestic investments (Claudia and Lipponer, 2005).

On the other hand, some empirical studies demonstrate supportive evidences using specific country data. Asheghian (2004) and Salehizadeh (2005) asserted the existence of a positive and significant relationship between FDI and the economic growth in the United States. A number of studies find that FDI inflows have a strong and positive effect on economic growth in China (Tian et al., 2004; Fang \& Liu, 2007; Sharahili \& Liu, 2008). According to Kornecki \& Raghavan (2008), the Central and Eastern Europe (CEE) countries acknowledge FDI as an essential tool in the development and modernization of their economies. Manal \& Liu (2011) have empirically analyzed Malaysia annual data and proved the bi-directional causality and long-run relationships between inward FDI and economic growth. Back to the case of Qatar, Shotar M Manhal (2005) supported that, the causal direction in Qatar runs from GDP to FDI which implies that economic growth is a prerequisite to attract FDI, during the period of 1980-2002. The present paper resets the sample period from 1990-2010 and re-investigates the type of the supposed causal relationship, either bi-causal link, or growth-driven FDI, or FDI-led growth.

\section{Hypothesis and Data}

Since related researches in Qatar case are limited, the research hypothesis in this study is going to be formulated from its economic fact. In Figure 1, the evolution of real GDP in Qatar has been convinced a steady ascent during the last two decades and the economy speeded up especially after 2002. This may attribute to the developments of more effective fiscal policy and the building of the positive business environment as well as the enhancing of the importance of the private sector. Moreover, the increased oil prices in 1999 have created a surplus in government budget and sustained the economic growth. Meanwhile, FDI inflows also experienced upward trend, just after a short decline during 2006 to 2008 a strong surge occurred in 2009. This may be mainly due to the turmoil of the international oil market and Qatar's openness primarily lies in the enhanced oil recovery and production sectors. From Figure 1, it is hardly to see any similar movements between the two.

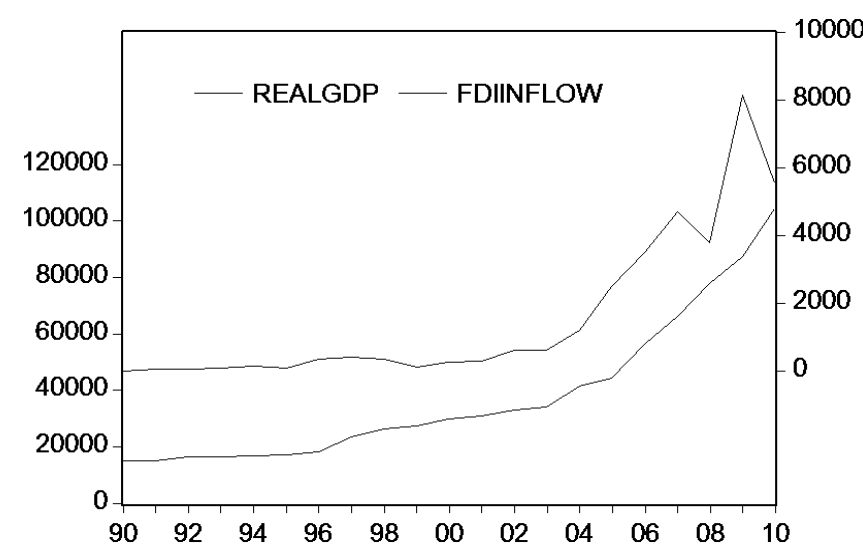

Figure 1. The real GDP and the inward FDI of Qatar (1990-2010)

But if comparing the growth rates of the real GDP and the Inward FDI of Qatar within the same period as shown in Figure 2, it can be clearly seen that the two curves moved at some similar pace. For example, during 1994-1998, both reached peak. The period between 1999 and 2008 convinced a relatively stable movement in both growth rate curves. Then from 2009 onward, both curves declined sharply. Therefore, it could initially assume that Qatar's inward FDI and the economic growth are significantly related in a long term. But to empirically prove it will be presented in the next section. The data of GDP and FDI inflows of Qatar were taken from the United Nations Conference on Trade and Development (UNCTAD) and the World Bank's World Development Indicators (WDI) \& Global Development Financial (GDF) from World Bank website. Annual time series data covers from1990 to 2010 as available online. 


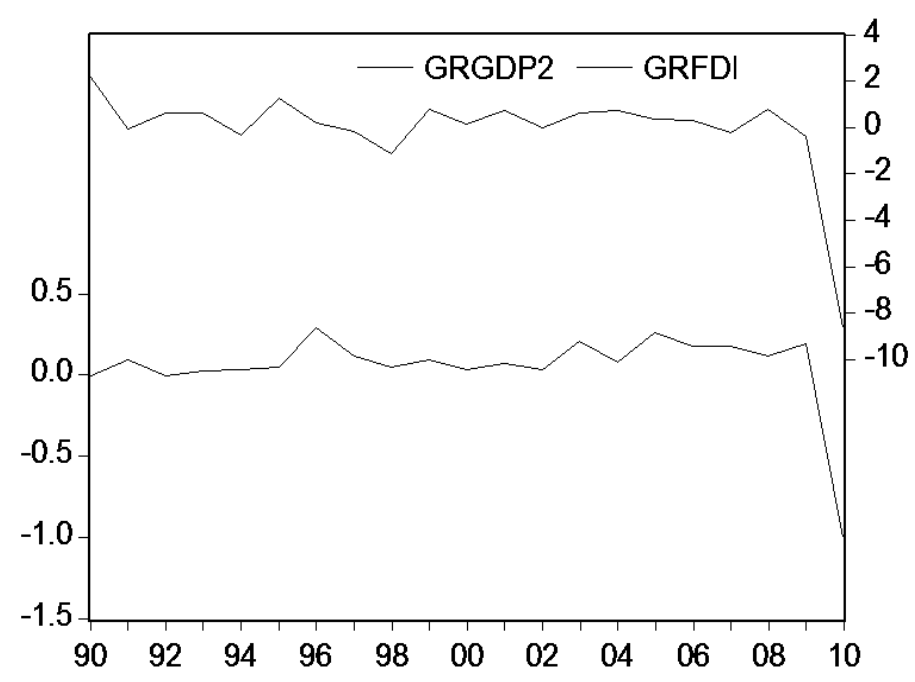

Figure 2. The growth rate of the real GDP and the inward FDI of Qatar (1990-2010)

\section{Models, Results and Discussions}

\subsection{Granger Causality Test}

Firstly, Granger Causality was tested to determine whether the economic growth (the FDI in flows is useful to in forecasting the FDI inflows (the economic growth). As to avoid the high probability of instability of the absolute time-series data, this study loginized the absolute value of GDP and the FDI inflows, noted as lnYt (LNGDP) and $\operatorname{lnFt}(\mathrm{LNFDI})$ respectively. The augmented auto-regression models were constructed as:

$$
\begin{aligned}
& \text { MI: } \ln Y_{t}=a 0+a 1 \ln Y_{t-1}+a 2 \ln F_{t}+a 3 \ln F_{t-1}+\mu 1 t \\
& \text { MII: } \ln F_{t}=b 0+b 1 \ln F_{t-1}+b 2 \ln Y_{t}+b 3 \ln Y_{t-1}+\mu 2 t
\end{aligned}
$$

The null hypothesis of $\mathrm{M} \mathrm{I}$ is $\mathrm{H} 0: \mathrm{a} 1=\mathrm{a} 2=\mathrm{a} 3=0$, which means the growth of FDI inflows does not contribute to the increase of GDP. If all the values of $\operatorname{lnF}$ and $\ln \mathrm{F}_{\mathrm{t}-1}$ (with lagged values of $\ln \mathrm{Y}_{\mathrm{t}-1}$ also included) are significant through a series of T-tests and F-tests, the null hypothesis shall be rejected since those values provide statistically significant information about future values of $\ln Y$.

Similarly, the null hypothesis of M II is H0: b11 = b20=b21=0, that is, the growth of GDP doesnot induce the increase of FDI inflows. And if all the values of $\ln \mathrm{Y}_{\mathrm{t}}$ and $\ln \mathrm{Y}_{\mathrm{t}-1}$ (with lagged values of $\ln \mathrm{F}_{\mathrm{t}-1}$ also included) through a series of T-tests and F-tests, are significantly high, the null hypothesis shall be rejected since those values provide statistically significant information to predict the future values of $\operatorname{lnF}_{\mathrm{t}}$. Otherwise, the null hypotheses shall be accepted, that is, the FDI inflows (the Economic Growth) does not granger-cause the Economic growth (the FDI inflows).

The OLS estimation results of the above models by running EViews6.0 are summarized in Table 1. It can be seen that F-value of MI is 502.9100. Given $\alpha=0.05$, the F-value is much larger than $\mathrm{F}_{0.05}(3,16)$. Thus, under the significance of $95 \%$, Model I is tested to be robust. Thus, the null hypothesis should be rejected, which indicates that the FDI inflows granger cause the growth of GDP. For MII, the obtained F-value (49.20290) also exceeds F0.05 $(3,16)$. Thus, GDP in turn granger cause the inward FDI. Therefore, it could roughly recognize that the growth of FDI inflows and the economic growth in Qatar are Granger Causality related.

More specifically, to observe the T-values of each coefficient. In M1, the current and the former period of FDI inflows negatively influence the current period of GDP; while only the former period of GDP exerts positive impacts on the current period of GDP. It indicates that the growth of Qatar economy is more contributed by the former growth itself. In MII, the former period of FDI inflows and the former period of GDP have positive impacts on the current period of inward FDI, while the current period of GDP pushes from the opposite direction. It implies that to attract FDI inflows the previous FDI inflow record and the previous economic performance are important indicators to refer to. 
Table 1. Results of granger causality test for economic growth and FDI inflows

\begin{tabular}{|c|c|c|c|c|c|c|c|}
\hline \multicolumn{4}{|c|}{ M I } & \multicolumn{4}{|c|}{ M II } \\
\hline Variables & coefficient & T-value & Prob. & Variables & coefficient & T-value & Prob. \\
\hline$a_{0}$ & -0.362903 & -0.529052 & 0.6040 & $\mathrm{~b}_{0}$ & -14.05680 & -2.275001 & 0.0370 \\
\hline $\ln Y_{t-1}$ & 1.052576 & 12.87243 & 0.0000 & $\ln F_{t-1}$ & 0.399913 & 1.436879 & 0.1700 \\
\hline $\operatorname{lnFt}$ & -0.026359 & -1.125197 & 0.2771 & $\ln Y_{t}$ & -2.781867 & -1.125197 & 0.2771 \\
\hline $\ln F_{t-1}$ & -0.019873 & -0.700871 & 0.4935 & $\ln \mathrm{Y}_{\mathrm{t}-1}$ & 4.435692 & 1.703026 & 0.1079 \\
\hline $\mathrm{R}^{2}$ & 0.989506 & & & $\mathrm{R}^{2}$ & 0.902206 & & \\
\hline $\mathrm{ADR}^{2}$ & 0.987539 & & & $\mathrm{ADR}^{2}$ & 0.883869 & & \\
\hline DW-value & 2.560424 & & & DW-value & 1.706248 & & \\
\hline F-value & 502.9100 & & & F-value & 49.20290 & & \\
\hline $\begin{array}{l}\text { Sample } \\
\text { range }\end{array}$ & $1990-2010$ & & & $\begin{array}{l}\text { Sample } \\
\text { range }\end{array}$ & $1990-2010$ & & \\
\hline
\end{tabular}

\subsection{VAR Impulse Responses}

After examining the patterns of the interactions above, Impulse Responses is conducted to uncover their responding sensitivities towards changes in a relatively longer term within vector-autoregressive (VAR) models. The loginized values of the GDP and the FDI inflows were differentiated to represent the growth rate of FDI inflows and GDP, noted as $\triangle \operatorname{lnYt}$ (DLNGDP) and $\triangle \operatorname{lnFt}$ (DLNFDI) respectively. A corresponding VAR model is constructed based on the theoretical principle of VAR Impulse Responses, to produce the time path of the dependent variables to the shocks from all the independent variables. If the system is stable, any shock should decline to zero; or an unstable system would produce an explosive time path. The results from running Eviews 6.0 are shown in Figure 3. The maximum lagged period is 2(AIC and SC).

Response to One S.D. Innovations $₫ 2$ S.E.
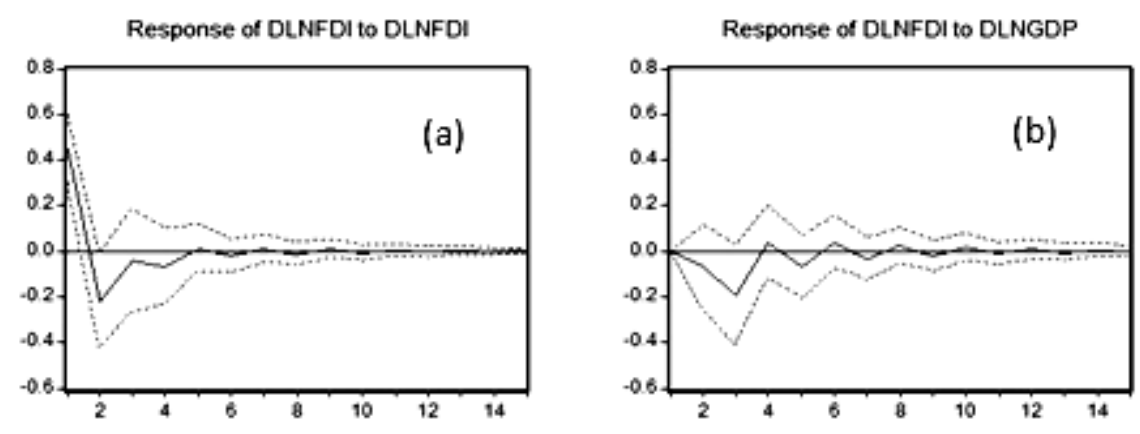

Response of DLNGDP to DLNFDI

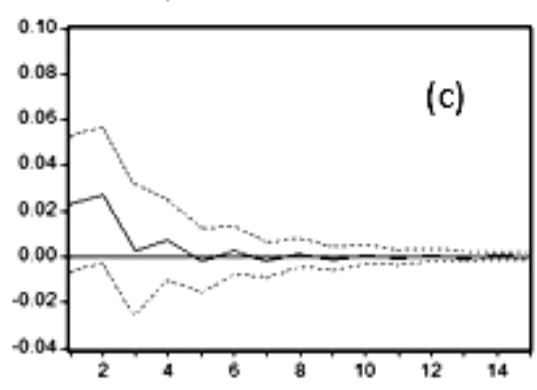

Response of DLNGDP to DLNGDP

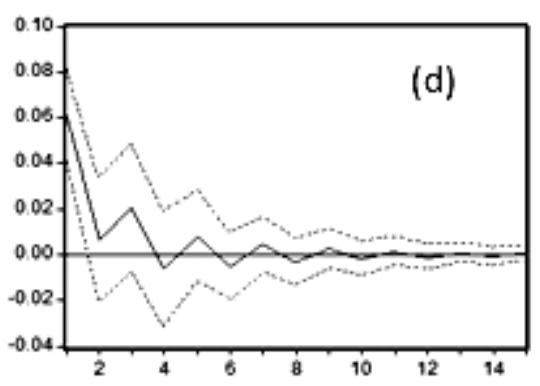

Figure 3. Results of VAR impulse responses tests

Comparing Figure 3 (a) and (b), the FDI inflows in Qatar respond more significantly to its own variance than to the 
variance of GDP, as its responding to its own variance starts from the first period while to the variance of GDP it starts from the second one. It implies that the FDI inflows of Qatar are more sensitive to its own fluctuation than to the fluctuation of the economic growth. Figure 3 (c) shows that the growth rate of Qatar GDP responds significantly and rapidly to the variance of inward FDI, for it starts responding from the first period until the fifth one and after the fifth period its response comes to be stable. But when the growth rate of Qatar GDP responses to its own variance in Figure 3 (d), it takes six periods to come to be stable. Thus, it suggests that the economic growth of Qatar is more sensitive to the fluctuation of FDI inflows, comparing with the fluctuation of the economic growth itself.

\section{Conclusions}

This paper has analyzed the relationships between FDI inflows and economic growth by using Qatar data and statistics (1990-2010). The empirical findings have clearly proved the afore-formulated hypothesis that Qatar's inward FDI and economic growth are Granger Causally related in a long term. Moreover, the inward FDI is positively affected by the economic growth, but more sensitive to its own performance change than to the economy growth. The economic growth is negatively affected by the inward FDI, and more sensitive to the inward FDI change than to the economic growth itself. Thus, it implies that to attract FDI inflows to Qatar, the government should continue its efforts to create promising economic and investment environment; while to promote economic growth, it shall attach more importance onto other original momentum.

\section{References}

Asheghian, P. (2004). Determinants of economic growth in the United States. The role of foreign direct investment. The International Trade Journal, 18(1), 63-83. http://dx.doi.org/10.1080/08853900490277350

Borensztein, E., De Gregorio, J., \& Lee, J. W. (1998). How does foreign direct investment affect economic $\begin{array}{llll}\text { growth? Journal of International Economics, } & 45,\end{array}$ http://dx.doi.org/10.1016/S0022-1996(97)00033-0

Brems, \& Hans. (1970). A Growth Model of International Direct Investment. The American Economic Review (AER), 60(3), 320-31. $\quad$ Retrieved from http://links.jstor.org/sici?sici=0002-8282\%28197006\%2960\%3A3\%3C320\%3AAGMOID\%3E2.0.CO\%3B 2-C\&origin=repec

Claudia M. B., \& Alexander L. (2005). Business Cycles and FDI: Evidence from German Sectoral DataKiel. Institute for World Economics. http://dx.doi.org/10.1007/s10290-005-0053-5

De Mello, \& JrLuiz R. (1999). Foreign Direct Investment-led growth: evidence from time series and panel data. Oxford Economic Papers, 51, 133-151. Retrieved from http://EconPapers.repec.org/RePEc:oup:oxecpp:v:51:y:1999:i:1:p:133-51

Ghironi, F., \& M. J. Melitz. (2004). International Trade and Macroeconomic Dynamics with 7. Heterogeneous Firms. NBER Working Paper 10540. National Bureau of Economic Research, Cambridge, Mass.

Hansen H., \& Rand, J. (2006). On the casual links between FDI and growth in developing countries. The World Economy, 29(1), 21. http://dx.doi.org/10.1111/j.1467-9701.2006.00756.x

Hanson, G. H., \& M. J. Slaughter. (2003). The Role of Multinational Corporations in International Business Cycle Transmission: Skew Lines or Arbitrage Opportunities? University of San Diego, Tuck School of Business at Dartmouth and NBER http://www.uni-iel.de/ifw/konfer/kwc/slaughter.pdf.

Karimi, Mohammad S., \& Yusop, Z. (2009). FDI and Economic Growth in Malaysia. Retrieved from http://mpra.ub.uni-muenchen.de/14999/

Kornecki, L., \& Raghavan, S. (2008). FDI and Economic Growth: an Empirical Analysis of Central and Eastern European Countries. European Journal of Management, 8(4).

ManalSuliman O., \& Liu Yao. (2011). Empirical Analysis of the Relationships between inward FDI and Business Cycles in Malaysia. Modern Applied Science, 5(3), 157-163.

Qiyun Fang, \& Yao Liu. (2007). Empirical Analysis: Business Cycles and Inward FDI in China. American Journal of Applied Sciences, 4(8), 800-804. http://dx.doi.org/10.3844/ajassp.2007.802.806

Reyadh Y. F., \& Khalifa H. G. (2009). Foreign Direct Investment and Economic Growth: The Case of the GCC Countries. International Research Journal of Finance and Economics, 29, 134-145. 
Salehizadeh, M. (2005). Foreign Direct Investment Inflows and the US Economy: An Empirical Analysis. Economic Issues, 10(2), 29-50. Retrieved from ABI/INFORM Global database.

Shotar M. M. (2005). The Attractiveness of Qatar to Foreign Direct Investment, 1980-2002. Applied Econometrics and International Development, 5-3(2005), 117-132.

Tian, X., Lin, S., \& Lo, V. I. (2004). Foreign Direct Investment and economic performance in transition economies: Evidence from China. Post-Communist Economies, 16(4), 499-510. http://dx.doi.org/10.1080/1463137042000309584

Yahya S., \& Yao Liu. (2008). Empirical Analysis II: Business Cycles and Inward FDI in China. American Journal of Applied Sciences, 5(10), 1409-1414. http://dx.doi.org/10.3844/ajassp.2008.1409.1414 